\title{
HUBUNGAN PERSEPSI RISIKO DENGAN KEINGINAN SISWI DALAM MENJAGA HIGIENE MENSTRUASI DI SEKOLAH DASAR KAMONING SAMPANG
}

\section{THE RELATIONSHIP BETWEEN PERCEPTION OF RISK AND FEMALE STUDENTS' DESIRE IN KEEPING MENSTRUAL HYGIENE AT SDN KAMONING SAMPANG}

\author{
Nurul Lailatul Badriyah ${ }^{1}$, Ira Nurmala ${ }^{2}$ \\ ${ }^{1}$ Puskesmas Torjun, Kabupaten Sampang, Madura, Indonesia \\ ${ }^{2}$ Fakutas Kesehatan Masyarakat Universitas Airlangga, Surabaya, Indonesia \\ Alamat Korespondensi: Nurul Lailatul Badriyah \\ Email : nlailatulbadriyah@gmail.com
}

\begin{abstract}
Maintaining menstrual hygiene is essential to avoid vulvar pruritus, irritation, swelling, vaginal secretions, reproductive tract infections, urinary tract infections, uterine cancer, etc. Sampang is the region with the highest maternal mortality rate in Madura, but recently, maternal mortality rate in Sampang continues to decline. One of the causes of maternal death is due to the lack of reproductive hygiene maintenance during menstruation, so that mothers are at risk of uterine cancer. The present study aimed to analyze the relationship between risk perception and female students' desire in SDN Kamoning in maintaining menstrual hygiene. It was an observational analytic research using cross sectional research design. This study employed HAPA theory. Health Action Process Approach (HAPA) is a concept approach to change one's behavior by strengthening intention to become action. The variable of risk in HAPA theory can influence individual perception early in the motivation phase. The samples of the study were 32 people, and they were taken by total sampling because the number of samples was very small. Data were collected through questionnaire, and they were analyzed by using spearman correlation. The results showed that there was correlation between perception of risk $(p=0,000)$ and intention to maintain menstrual hygiene. Relationships obtained were not strong because some respondents did not agree with the statements in the questionnaire. It can be concluded that there is a relationship between risk perception and intention to maintain personal hygiene during menstruation. Although the relationship obtained showed a strong relationship, there were some female students that still had wrong perception about personal hygiene maintenance during menstruation.
\end{abstract}

Keyword : menstrual hygiene, HAPA, kamoning elementary school

\begin{abstract}
ABSTRAK
Menjaga higiene menstruasi sangat penting agar terhindar dari pruritus vulva, iritasi, inflamasi, sekresi vaginal, infeksi saluran reproduksi, infeksi saluran kemih, kanker rahim dll. Sampang merupakan daerah dengan kematian ibu tertinggi di Madura, namun angka kematian ibu di Sampang terus menurun. Kanker rahim merupakan salah satu faktor risiko terjadinya kematian Ibu di Sampang. Penyebab kanker rahim salah satunya karena tidak menjaga higiene menstruasi. Penelitian ini bertujuan untuk menganalisis hubungan persepsi risiko dengan keinginan siswi SDN Kamoning dalam menjaga higiene menstruasi. Penelitian ini merupakan penelitian observasional analitik, menggunakan desain penelitian cross sectional. Konsep yang digunakan dalam penelitian ini ialah teori HAPA (Health Action Process Approach). Variabel yag diteliti pada teori HAPA yaitu persepsi risiko dan keinginan seseorang. Sampel penelitian sebanyak 32 orang, yang diambil dengan cara total populasi. Pengumpulan data menggunakan kuesioner dan analisis data menggunakan korelasi spearman. Hasil penelitian menunjukkan terdapat hubungan antara persepsi risiko dengan keinginan untuk menjaga higiene menstruasi $(p=0,000)$. Kesimpulan nya adalah ada hubungan antara persepsi risiko dengan keinginan dalam menjaga higiene menstruasi, sehingga seseorang yang masih memiliki persepsi risiko keliru cenderung tidak melakukan higiene menstruasi.
\end{abstract}

Kata kunci : higiene menstruasi, HAPA, SDN kamoning 


\section{PENDAHULUAN}

WHO adalah keadaan sehat yang menyeluruh, meliputi aspek fisik, mental, dan sosial dan bukan sekedar tidak adanya penyakit atau gangguan di segala hal yang berkaitan dengan sistem reproduksi, fungsinya maupun proses reproduksi itu sendiri. Kesehatan reproduksi merupakan komponen penting kesehatan bagi pria dan wanita, namun lebih dititikberatkan pada wanita karena wanita memiliki sistem reproduksi yang sensitif terhadap suatu penyakit. Suatu keadaan penyakit lebih banyak dihubungkan dengan fungsi dan kemampuan reproduksinya (Kusmiran, 2012). Kesehatan reproduksi memiliki permasalahan seperti hak-hak reproduksi, masalah seksual, dan Penyakit Menular Seksual (PMS) (Mahfiana et.al., 2009). Tingginya usia perkawinan dibawah 20 tahun $(4,8 \%$ usia $10-14$ tahun, $41,9 \%$ pada usia 15-19 tahun) dan usia pertama kali menstruasi (menarche) yang masih muda yang bisa menyebabkan usia reproduksi perempuan semakin panjang merupakan awal permasalahan kesehatan pada wanita (Riskesdas, 2010).

Menstruasi adalah keluarnya darah dari kemaluan setiap bulan akibat meluruhnya dinding rahim (endometrium) yang mengandung pembuluh darah karena sel telur (ovum) tidak dibuahi (Pudiastuti, 2012). Menarche merupakan haid pertama wanita yang terjadi karena proses sistem hormonal yang kompleks dimana cairan darah keluar dari alat kelamin wanita yang berasal dari luruhnya lapisan dinding dalam rahim (endometrium) (Pudiastuti, 2012). Remaja yang telah mengalami Menarche merupakan salah satu tanda bahwa dia mengalami perubahan di dalam dirinya dan juga disertai dengan berbagai masalah dan perubahan-perubahan baik fisik, biologi, psikologi maupun sosial, harus dihadapi oleh remaja karena ini merupakan masa yang sangat penting karena merupakan masa peralihan ke masa dewasa.
Usia menarche umumnya terjadi antara usia 9 sampai 15 tahun (Santrock, 2003). Pulungan (2009) juga mengatakan bahwa usia menarche remaja putri berkisar pada usia termuda 8 tahun dan usia tertua adalah 14 tahun. Hasil Riset Kesehatan Dasar (2010) menunjukkan rata-rata usia menarche terjadi lebih dini karena anak perempuan mengalami menstruasi pertama pada usia kurang dan atau sama dengan 10 tahun.

Pembuluh darah dalam rahim sangat mudah terinfeksi ketika menstruasi karena kuman mudah masuk dan menimbulkan penyakit pada saluran reproduksi (Kusmiran, 2012). Infeksi ini biasanya diakibatkan oleh salah satu organisme berikut : Candida albicans, Trichomonas vaginalis dan Gardnerella vaginalis yang dapat menyebabkan gejala seperti pruritus vulva, iritasi, inflamasi, sekresi vaginal, dan rasa perih. Hasil penelitian Panda (2013) menunjukkan bahwa pada 50 kasus pada penderita lekore (keputihan) terdapat 26 kasus $(52 \%)$ terjadi infeksi oleh Candida, 3 kasus $(6 \%)$ oleh Trichomanas vaginalis dan infeksi oleh keduanya adalah 4 kasus (8\%). Penelitian ini menunjukkan bahwa Candida albicans merupakan spesies Candida yang paling sering menyebabkan keputihan. Infeksi dan masalah vagina diatas dipengaruhi oleh infeksi bakteri,virus, jamur dan parasit (Pudiastuti, 2012). Selain itu, terjadi iritasi pada vagina akibat bahan kimia atau fisik (seperti sabun, spermisida, pembalut, dan lain-lain), alergi dan dermatitis kontak serta adanya penyebab lain seperti polip servikalis/neoplasma (Davey, 2005).

Menjaga higiene menstruasi sangat penting agar terhindar dari infeksi yang diakibatkan organisme yang dapat menyebabkan gejala seperti pruritus vulva, iritasi, inflamasi, sekresi vaginal, dan rasa perih. Adapun penyebab infeksi tersering adalah Vagionosis bakterialis (40-50\%), Candiasis (20-30\%) dan Trichomoniasis vaginalis bakterialis (15-20\%) (Davey 2005 dalam penelitian Fitriyah 2014). Menurut penelitian (Panda) terdapat 52\% 
infeksi disebabkan Candida, $6 \%$ disebabkan Trichomonas vaginalis, dan $8 \%$ infeksi disebabkan keduanya. Menurut penelitian Fitriyah (2014) tentang gambaran perilaku higiene menstruasi pada remaja putri di SDN wilayah kerja Puskesmas Pisangan didapatkan hasil sebanyak $61 \%$ siswi sekolah dasar negeri mengalami gatalgatal saat menstruasi.

Higiene menstruasi yang rendah bisa menyebabkan infeksi saluran kemih karena saluran kemih bawah perempuan lebih pendek dibandingkan saluran kemih laki-laki. Bila permukaan kemaluan wanita atau vulva kurang bersih, hal tersebut karena remaja putri salah dalam membersihkan kemaluannya, pakaian dalamnya, ataupun pembalut yang dipakai maka muara saluran kemih atau tempat keluarnya air seni mudah tercemar bibit penyakit. Infeksi yang disebabkan bibit penyakit menimbulkan peradangan saluran kemih bagian bawah, yang gejalanya berupa nyeri dan sakit setiap kali berkemih, dan bisa sampai urin bercampur dengan darah (Proverawati \& Misaroh, 2009). Higiene menstruasi pada remaja putri tergolong buruk masing-masing $68,3 \%$ dan $77,5 \%$. Sekitar $82,6 \%$ higiene menstruasi rendah karena remaja putri kurang mendapatkan informasi masalah higiene menstruasi (Suryati, 2012).

Dampak kurangnya menjaga higiene menstruasi juga dapat menyebabkan Infeksi Saluran Reproduksi (ISR). Penyebab utama penyakit ISR yaitu imunitas lemah (10\%), kurangnya menjaga higiene menstruasi (30\%), dan lingkungan yang tidak bersih serta penggunaan pembalut yang kurang sehat saat menstruasi (50\%) (Rahmatika, 2012). Jumlah kasus infeksi saluran reproduksi yang terjadi pada remaja putri seperti Candidiasis dan Cervisitis sebanyak $86,5 \%$ ditemukan di Surabaya dan Malang. Penyebab tertinggi dari kasus tersebut adalah jamur Candida albican sebanyak $77 \%$ yang berkembang biak dengan kelembapan tinggi seperti pada saat menstruasi.
Perempuan yang memiliki riwayat infeksi saluran reproduksi (ISR) mempunyai dampak buruk untuk masa depannya seperti kanker rahim (Rahayu, 2012). Kanker rahim merupakan pembunuh nomor satu bagi wanita dengan angka insiden kanker rahim mencapai 100 per 100.000 penduduk pertahun yang bisa berujung dengan kematian (Iskandar, 2015). Penderita kanker rahim di Indonesia diperkirakan $90-100$ per 100.000 penduduk (Nasdaldy, 2012).

Penelitian

Indah

menunjukkan bahwa remaja putri di SMAN 1 Ngimbangan $100 \%$ pernah mengalami pruritus vulvae saat menstruasi yaitu 12 orang $(15,2 \%)$, mengalami pruritus vulvae setiap hari selama menstruasi dan 67 orang $(84,8 \%)$ merasakan pruritus vulvae namun tidak setiap hari selama menstruasi. pruritus vulvae kronis tersebut disebabkan oleh jamur, bakteri, dan virus yang muncul karena buruknya personal higiene dan higiene menstruasi (44\%) karena alergen dan produk kewanitaan (30\%) serta karena kelainan patologik pada vulvae $(26 \%)$.

Sampang merupakan daerah dengan kematian ibu tertinggi di Madura, namun angka kematian ibu di Sampang terus menurun (Sulaiman, 2017). Salah satu penyebab kematian ibu karena kurangnya menjaga higiene alat reproduksi dan saat menstruasi, sehingga ibu berisiko terkena kanker rahim. Setiap tahunnya terjadi kematian ibu karena kanker rahim, khususnya di Desa Kamoning sejak tahun 2015 . Kejadian kematian ibu karena kejadian kanker rahim sebanyak 3 orang dan meningkat pada tahun 2016 sebanyak 5 orang (Puskesmas Kamoning, 2016). Berdasarkan data yang didapatkan dari Puskesmas Kamoning Sampang, remaja putri dalam menjaga kebersihan diri dan menstruasi tergolong buruk masing-masing $69 \%$ dan $78,5 \%$.

Puskesmas Kamoning memiliki program pencegahan penyakit yang disebabkan karena tidak menjaga higiene saat menstruasi yaitu Program Kesehatan Reproduksi Remaja (KRR). Program 
tersebut tidak pernah memberikan edukasi kepada siswi SDN Kamoning karena sasaran program hanya remaja SMP/MTsN dan SMA/MAN. Berdasarkan narasumber di Puskesmas Kamoning terdapat beberapa siswi SDN Kamoning yang memiliki keluhan gatal-gatal saat menstruasi. Puskesmas tidak pernah memberikan edukasi kepada anak SD karena sasaran program KRR hanya remaja SMP/MTsN dan SMA/MAN.

Persepsi risiko merupakan gambaran/pandangan seseorang terhadap risiko yang akan terjadi jika melakukan/tidak melakukan tindakan. Persepsi risiko berfungsi untuk mempengaruhi persepsi individu di awal fase motivasi, sehingga penelitian ini bertujuan untuk menganalisis hubungan persepsi risiko dengan keinginan siswi dalam menjaga higiene menstruasi di SDN Kamoning Sampang.

\section{METODE PENELITIAN}

Berdasarkan jenisnya penelitian ini merupakan penelitian observasional analitik karena peneliti tidak melakukan perlakuan pada sampel yang diteliti. Penelitian ini menggunakan metode kuantitatif dengan desain cross sectional yaitu pengambilan data hanya dilakukan sekali tanpa pengulangan penelitian dan intervensi apapun (Setiawan \& Saryono, 2010). Populasi yang diteliti adalah seluruh remaja putri kelas 5 dan 6 yang sudah mengalami menstruasi di SDN Kamoning sebanyak 32. Besar sampel penelitian ini sebanyak 32 siswi yang terdiri dari siswi SDN Kamoning I yang sudah menstruasi sebanyak 22 orang, siswi SDN Kamoning II yang sudah menstruasi sebanyak 7 orang dan siswi SDN Kamoning III yang sudah menstruasi sebanyak 3 orang.

Pengambilan sampel dalam penelitian ini dengan cara mengunjungi masing-masing sekolah guna mengetahui jumlah siswi yang sesuai dengan kriteria penelitian. Pada proses pengambilan sampel, peneliti didampingi wali murid ke kelas untuk menyampaikan maksud dan tujuan, sehingga diperoleh 32 siswi. Peneliti menggunakan teknik total populasi karena populasi tersebut menurut peneliti sangat sedikit atau kurang dari 100 sehingga diambil semua oleh peneliti (Sugiyono, 2007).

Penelitian ini dilaksanakan di Sekolah Dasar di Desa Kamoning. Pengumpulan datanya menggunakan pendekatan kuantitatif dengan cara pengisian kuesioner dan pengolahan data dilakukan dengan cara editing, scoring, coding, dan entry sedangkan untuk analisis data menggunakan Uji Korelasi Spearman untuk mengetahui hubungan antara variabel persepsi risiko dengan variabel keinginan siswi untuk melakukan higiene menstruasi.

Tehnik pengumpulan data menggunakan data primer dan data sekunder. Data primer didapatkan dengan cara melakukan studi awal dan pemberian kuesioner kepada siswi kelas 5 dan 6 yang sudah menstruasi, sedangkan data sekunder didapatkan dari studi pustaka seperti literatur, jurnal, referensi yang berhubungan dengan obyek penelitian dan data jumlah SDN Kamoning melalui Puskesmas Kamoning.

Teknik yang digunakan untuk menganalisis data yaitu analisis univariat dan bivariat. Analisis univariat dilakukan untuk mendapatkan gambaran umum SDN Kamoning Sampang dan distribusi frekuensi dari variabel yang diamati. Analisis bivariat dilakukan untuk mengetahui hubungan antara variabel persepsi risiko dengan keinginan bertindak menggunakan uji korelasi spearmen.

Health Action Process Approach (HAPA) merupakan suatu konsep pendekatan yang meyakini untuk mengubah perilaku seseorang dapat dilakukan dengan cara meningkatkan keinginan melalui fase motivasi untuk membentuk keinginan menjadi action (Bandura, 1977). Fase motivasi dari teori HAPA terdiri dari persepsi risiko, harapan hasil, dan kemampuan diri. Variabel tersebut mempengaruhi keinginan seseorang untuk 
melakukan sesuatu, akan tetapi persepsi risiko berfungsi untuk mempengaruhi persepsi individu di awal fase motivasi, sehingga varibel yang diteliti adalah persepsi risiko dan keinginan siswi dalam menjaga higiene menstruasi.

\section{HASIL}

\section{Gambaran Umum Lokasi Penelitian}

SDN Kamoning terletak di Desa Kamoning, Kecamatan Sampang, Kabupaten Sampang, Madura, Jawa Timur. Posisi geografis lokasi tersebut adalah $111.2375^{\circ}$ Bujur Timur dan $-7.160065^{\circ}$ Lintang Selatan. SDN Kamoning didirikan pada tanggal 1 januari 1941 di Desa Kamoning Sampang. Sekolah Dasar Negeri Kamonig terdiri dari SDN Kamoning I, II, dan III. Tenanga pengajar di SDN Kamoning sebanyak 24 orang yang terdiri dari 15 orang berstatus PNS dengan pendidikan terakhir S1, 2 orang PNS dengan pendidikan terakhir S2, dan 7 orang tenaga honorer.

Kondisi prasarana di SDN Kamoning banyak yang mengalami kerusakan berat seperti ruang kelas 1 sampai kelas 6, Unit Kesehatan Sekolah (UKS), perpustakaan, dan ruang guru yang tidak mengalami kerusakan. Lingkungan sekolah di SDN Kamoning memiliki sanitasi yang kurang baik karena ketersediaan air bersih/kecukupan air masih kurang, tidak tersedia toilet berkebutuhan khusus, sumber air sanitasi dan Leden/PAM, tipe jamban dari leher angsa, tidak tersedia tempat cuci tangan, sabun cuci tangan dan tisu di toilet.

Kamar mandi/wc yang disediakan di SDN Kamoning 1 sebanyak 3 dengan jumlah murid 300 dan tidak dipisah, sedangkan di SDN Kamoning II menyediakan 2 kamar mandi yang tidak dipisah dengan murid sebanyak 135, dan SDN Kamoning III menyediakan 2 kamar mandi yang tidak dipisah dengan jumlah murid 90.

\section{Gambaran Karakteristik Responden}

Siswi SDN Kamoning yang sudah menstruasi mayoritas berada pada kelas 5 dan 6. Sebagian besar usia responden adalah 12 tahun dan yang paling tua adalah 13 tahun. Siswi menstruasi dengan usia muda berumur 11 tahun yang duduk di bangku kelas 5, sedangkan umur tertua menduduki bangku kelas 6. Sebagian responden yang sudah menstruasi mengaku pernah mengalami gatal-gatal, perih, iritasi sampai kulit kemerah-merahan karena siswi tidak pernah diberi edukasi tentang higiene menstruasi sehingga siswi tidak tahu cara menjaga higiene menstruasi. Berikut tabel jumlah siswi SDN Kamoning yang sudah menstruasi.

Tabel 1. Jumlah Siswi SDN Kamoning Yang Sudah Menstruasi Tahun 2017

\begin{tabular}{cccccccc}
\hline \multirow{2}{*}{ Haid } & \multicolumn{2}{c}{ SD } & \multicolumn{2}{c}{ SD } & \multicolumn{2}{c}{ SD } & \multirow{2}{*}{ I } \\
\cline { 2 - 8 } & V & VI & V & VI & V & VI & \\
\hline Belum & 10 & 3 & 4 & 4 & 4 & 3 & 28 \\
\hline Sudah & 7 & 15 & 1 & 6 & 1 & 2 & 32 \\
\hline
\end{tabular}

Tabel 1 menjelaskan bahwa jumlah siswi SDN Kamoning sebanyak 60 orang. Siswi yang belum menstruasi sebanyak 28 orang dan yang sudah menstruasi 32 orang. Siswi terbanyak yang mengalami menstruasi berasal dari SDN Kamoning I sebanyak 22 orang dan yang paling sedikit berasal dari SDN Kamoning III sebanyak 3 orang.

\section{Persepsi Risiko Tidak Menjaga Higiene Menstruasi}

Persepsi risiko merupakan anggapan siswi tentang kurangnya menjaga higiene menstruasi. sebagian besar siswi memiliki persepsi keliru tentang cara membasuh alat kelamin, penggunaan pembalut, waktu ganti pembalut, dll. Tabel dibawah ini menunjukkan distribusi 
persepsi risiko tidak menjaga higiene menstruasi pada siswi SDN Kamoning.

Tabel 2. Distribusi Persepsi Risiko Dampak Keputihan Pada Siswi SDN Kamoning Tahun 2017

\begin{tabular}{lcr}
\hline Persepsi Risiko & $\begin{array}{c}\text { Frekuensi } \\
(\mathbf{n})\end{array}$ & $\mathbf{( \% )}$ \\
\hline Persepsi Keliru & 17 & 53,1 \\
Persepsi Sedang & 15 & 46,8 \\
Persepsi Benar & 0 & 0 \\
\hline \multicolumn{2}{c}{ Tabel 2 menunjukkan lebih dari }
\end{tabular}

separuh responden banyak yang memiliki persepsi risiko yang keliru tentang higiene menstruasi, sedangkan siswi yang memiliki persepsi sedang dalam menjaga higiene menstruasi sebesar $46,8 \%$, dan tidak ada siswi yang memiliki persepsi yang benar tentang risiko jika tidak menjaga higiene menstruasi.

\section{Keinginan Dalam Menjaga Higiene Menstruasi}

Siswi akan terhindar dari penyakit yang berhubungan dengan higiene menstruasi yang rendah jika dia melakukan higiene menstruasi dengan baik. Seorang melakukan suatu tindakan sebelumnya dia memiliki keinginan yang kuat untuk

\section{Hubungan Persepsi Risiko Tidak Menjaga Higiene Menstruasi Dengan Keinginan Siswi Dalam Menjaga Higiene Menstruasi}

Teori HAPA menjelaskan bahwa niatan seseorang untuk melakukan suatu tindakan memiliki hubungan dengan persepsi risiko. Berikut tabel yang menunjukkan hubungan antara persepsi risiko (Tidak mengganti pembalut setelah buang air kecil/besar, penggunaan pembalut yang tidak bersih, tidak mengganti celana dalam minimal dua kali sehari, tidak membasuh alat kelamin dari depan ke beakang, penggunaan celana dalam ketat, tidak mencuci tangan sebelum meyentuh alat kelamin, menggunakan sabun/bahan kimia untuk membersihkan alat kelamin melakukan tindakan tersebut. Pada tabel dibawah ini menunjukkan keinginan siswi SDN Kamoning untuk melakukan higiene menstruasi.

Tabel 3. Keinginan Siswi SDN Kamoning Dalam Menjaga Higiene Menstruasi Tahun 2017

\begin{tabular}{ccc}
\hline Keinginan & $\begin{array}{c}\text { Frekuensi } \\
(\mathbf{n})\end{array}$ & $\begin{array}{c}\text { Persentase } \\
(\boldsymbol{\%})\end{array}$ \\
\hline Tidak & 21 & 65,6 \\
Ya & 11 & 34,3 \\
Total & 32 & 100,0 \\
\hline
\end{tabular}

Tabel 3 menunjukkan bahwa masih banyak responden yang tidak memiliki keinginan untuk melakukan higiene menstruasi. Siswi yang tidak melakukan higiene menstruasi lebih dari 50\% responden. Siswi SDN Kamoning yang tidak memiliki keinginan melakukan higiene menstruasi karena beberapa responden ada yang tidak menjawab setuju tentang persepsi dampak penggunaan pembalut yang tidak bersih, tidak mencuci tangan sebelum menyentuh alat kelamin, tidak mengganti pembalut set celana dalam ketat, tidak mengganti celana dalam minimal dua kali sehari dll.

saat mandi atau setelah membasuh alat kelamin) dengan niat bertindak dalam menjaga higiene saat menstruasi.

Tabel 5. Hubungan Persepsi Risiko Dengan Niatan Siswi Dalam Menjaga Higiene Saat Menstruasi Tahun 2017.

\begin{tabular}{|c|c|c|c|c|c|}
\hline \multirow[b]{2}{*}{ Persepsi } & \multicolumn{2}{|c|}{ Niat } & \multirow{2}{*}{$\begin{array}{c}\text { To } \\
\text {-tal } \\
(\% \\
) \\
\end{array}$} & \multirow[b]{2}{*}{$\begin{array}{l}\text { Si } \\
\text { g. }\end{array}$} & \multirow{2}{*}{$\begin{array}{c}\text { Koef. } \\
\text { Kore- } \\
\text { Lasi }\end{array}$} \\
\hline & $\begin{array}{c}\text { Tidak } \\
(\%)\end{array}$ & $\begin{array}{c}\text { Ya } \\
(\%) \\
\text { (\%) } \\
\end{array}$ & & & \\
\hline Keliru & 50 & 3,1 & $\begin{array}{c}53 \\
1\end{array}$ & \multirow{2}{*}{$\begin{array}{l}0, \\
0\end{array}$} & \multirow[b]{2}{*}{0,639 ** } \\
\hline Benar & 15,6 & $\begin{array}{c}31, \\
2\end{array}$ & $\begin{array}{c}46 \\
8\end{array}$ & & \\
\hline
\end{tabular}

Tabel 5. Menunjukkan hasil analisis hubungan antara persepsi risiko dengan niatan bertindak dalam menjaga kebersihan 
diri saat menstruasi. Nilai koefisien korelasi yang didapat sebesar $0,639 * *$ dengan taraf signifikansi untuk hipotesis umum sebesar 0,000 pada tingkat taraf kepercayaan 0,05 atau $95 \%$ adapun tingkat kriteria pengujian

Jika taraf signifikansi kurang dari $\alpha$, maka $\mathrm{H} 0$ ditolak dan $\mathrm{H} 1$ diterima.

Jika taraf signifikansi lebih dari $\alpha$, maka $\mathrm{H} 0$ diterima dan $\mathrm{H} 1$ ditolak.

Hasil perhitungan diperoleh nilai signifikansi sebesar 0,000 kurang dari $\alpha$ $(0,05)$ maka hipotesis $\mathrm{H} 0$ ditolak atu $\mathrm{H} 1$ diterima, artinya terdapat hubungan yang signifikansi antara persepsi risiko dengan niatan bertindak dalam kebersihan diri saat menstruasi. Hubungan ini ditunjukkan dengan nilai korelasi sebesar 0,639 yang termasuk kedalam kategori tinggi $(0,61$ $0,80)$.

\section{PEMBAHASAN}

\section{Gambaran Karakteristik Responden}

Tahap perkembangan remaja dibagi menjadi tiga tahap yaitu remaja tahap awal (10-14 tahun), remaja tahap menengah (1516 tahun), dan remaja tahap akhir (17-21 tahun) (Bobak and Jensen, 2005). Pada penelitian ini menunjukkan responden berada pada rentang usia 10-14 tahun yang termasuk pada remaja tahap awal. Usia siswi kelas 5 dan 6 berkisar antara 11-13 tahun. Remaja awal akan mengalami suatu pertumbuhan fisik yang cepat dan disertai banyak perubahan, seperti pertumbuhan organ-organ reproduksi (Organ seksual) sehingga tercapai kematangan yang ditunjukkan dengan kemampuan melaksanakan fungsi reproduksi. Pada remaja putri memiliki tanda-tanda seks sekunder salah satunya menstruasi (Widyastuti, et al., 2009).

Menstruasi pertama dimulai pada usia 9 sampai 14 tahun. Rata-rata usia menstruasi di Indonesia yaitu usia 11,2-13,4 tahun, dengan umur terendah 9 tahun dan tinggi 15 tahun (Ginarhayu, 2013). Siswi SDN Kamoning mengalami menstruasi pertama di umur 11,12, dan 13 tahun. Perubahan dan perkembangan yang sedang dilalui oleh remaja sangat memerlukan bimbingan dan arahan yang dapat membatu remaja melewati masa pubertas dengan baik pada periode perkembangan remaja yang sedang dilaluinya. Saat mengalami menstruasi hal terpenting yang harus dilakukan adalah menjaga higiene menstruasi agar tehindar gangguan/penyakit yang berkaitan dengan dampak tidak menjaga higiene menstruasi seperti kulit kelamin mengalami gatal-gatal, kemerahan yang disebabkan karena terlalu sering di garuk, dan iritasi sampai terasa perih (Widyastuti, 2009).

\section{Persepsi Risiko Tidak Menjaga Higiene Menstruasi}

Beberapa siswi SDN Kamoning masih memiliki persepsi yang keliru tentang cara menjaga higiene menstruasi. Hal ini bisa dilihat dari jawaban responden bahwa lebih dari separuh responden menjawab tidak setuju tentang cara menjaga higiene menstruasi yang benar. Cara melakukan higiene menstruasi menurut Manan (2011) ialah : (1) Mencuci tangan sebelum menyentuh alat kelamin, (2) Membasuh alat kelamin dari depan kebelakang, (3) Membersihkan bekas keringat pada daerah alat kelamin dengan tisu, (4) Menggunakan pembalut yang bersih, (5) Mengganti pembalut setelah air kecil/buang air besar, (6) Tidak menggunakan celana dalam yang ketat, (7) Mengganti celana dalam 2 kali/lebih dalam sehari, (8) Tidak membersihkan alat kelamin menggunakan sabun.

Beberapa siswi menyatakan tidak setuju jika melakukan cuci tangan sebelum menyentuh alat kelamin. Hal ini sama dengan penelitian Fitriyah (2014) bahwa lebih dari separuh responden tidak setuju jika melakukan higiene menstruasi. Tidak mencuci tangan sebelum menyentuh organ kelamin bagian luar berisiko menimbulkan penyakit karena tangan yang tidak bersih terdapat kotoran dan bakteri. Jika bakteri 
tersebut berkembang biak dan memicu timbulnya penyakit (Anurogo and Wulandari, 2011).

Siswi SDN Kamoning juga masih memiliki persepsi yang keliru tentang cara membasuh alat kelamin dari depan ke belakang. Pada penelitian Kurniawati (2014) menjelaskan bahwa membasuh alat kelamin dari depan ke belakang dengan air bersih. Membasuh alat kelamin dari depan kebelakang adalah hal yang benar dan penting dilakukan agar bakteri di anus tidak terbawa ke dalam organ kelamin yang berisiko menimbulkan infeksi. Pada penelitian Rimawati (2012) juga menjelaskan bahwa cara menyeka yang benar adalah dari arah depan kebelakang agar bibit penyakit yang bersarang di anus tidak terbawa ke organ kelamin yang dapat menimbulkam infeksi, peradangan dan gatal-gatal.

Menjaga higiene menstruasi lainnya yaitu tidak membasuh alat kelamin dengan sabun yang akan membahayakan alat kelamin. Lebih dari separuh responden menyatakan tidak setuju jika membasuh alat kelamin dari depan kebelakang. Hal ini serupa dengan penelitian Fitriyah (2014) tentang gambaran perilaku higiene menstruasi pada remaja putri SDN Wilayah Kerja Puskesmas Pisangan. Penelitian tersebut menjelaskan bahwa lebih dari separuh respondennya setuju dengan pernyataan membersihkan alat kelamin menggunakan sabun. Setiap remaja yang sudah mengalami menstruasi sebaiknya tidak perlu menggunakan sabun khusus karena pada organ kelamin bagian luar terdapat kuman doderlin yang berfungsi memproduksi asam yang dapat mencegah bakteri masuk ke dalam organ kelamin. Jika kita membersihkan organ kelamin bagian luar menggunakan pembersih khusus secara rutin maka dapat membunuh kuman tersebut dan memicu bakteri jahat berkembang biak sehingga menyebabkan infeksi.

Penelitian Kurniawati (2014) menjelaskan bahwa responden mengetahui akibat tidak menjaga higiene menstruasi (keputihan), namun mereka masih belum mengetahui tentang bahaya penggunaan sabun kewanitan/bahan kimia yang dibasuhkan ke alat kelamin. Kebanyakan responden menganggap bahwa sabun kewanitaan/bahan kimia lainnya dapat mematikan bakteri tidak normal, tetapi nyatanya sabun tersebut bisa mematikan bakteri normal yang ada di daerah kewanitaan. Penggunaan sabun ini dapat mengubah kondisi lingkungan organ kelamin bagian luar sehingga bakteri yang tidak normal atau bakteri pengganggu dapat berkembang biak dan menyebabkan keputihan (Jones, 2009). Sabun kewanitaan dapat mematikan bakteri yang fungsinya untuk pertahanan diri terhadap infeksi (Yuliarti, 2014).

Mengeringkan alat kelamin dengan tisu masih jarang dilakukan oleh siswi SDN Kamoning, hampir sama dengan penelitian Fitriyah (2014) bahwa responden tidak mengeringkan organ kelamin bagian luar dengan tisu kering setelah membersihkan organ kelamin bagian luar. Mengeringkan alat kelamin dengan tisu kering dilakukan supaya organ kelamin bagian luar tidak lembab dan mencegah bakteri jahat tumbuh di daerah kemaluan (Kurniawati, 2014).

Perilaku lainnya untuk menjaga higiene menstruasi yaitu mengganti celana dalam 2 kali sehari/lebih. Siswi masih sedikit yang melakukan hal tersebut, hal ini bisa dilihat dari jawaban responden bahwa beberapa siswi menjawab tidak setuju jika mengganti celana minimal 2 kali dalam sehari. Hal ini juga sesuai dengan penelitian Fitriyah (2014) bahwa siswi jarang mengganti celana dalam minimal 2 kali sehari saat menstruasi. mengganti celana dalam secara rutin minimal 2 kali sehari atau segera ketika celana dalam terkena darah dapat mencegah organ kelamin bagian luar dari kelembapan yang berlebihan. Selain itu, infeksi juga sering terjadi akibat celana dalam yang tidak bersih (Kusmiran, 2012).

Beberapa siswi juga masih ada yang tidak mengganti pembalutnya setelah buang air kecil/besar, kemungkinan hal ini karena 
siswi tidak membawa pembalut saat di sekolah dan UKS tidak menyediakan pembalut bagi siswi yang sudah menstruasi. Hal ini sama dengan penelitian Fitriyah (2014) bahwa sebagian responden tidak mengganti pembalut setiap setelah buang air kecil/besar. Penggantian pembalut tidak boleh dari 6 jam, karena pembalut akan menyimpan bakteri ketika lama tidak diganti dan individu merasa tidak nyaman karena organ kelamin bagian luar lembab, mikroorganisme dan jamur akan berkembang biak sehingga dapat

mengganggu ekosistem vagina yang bisa menyebabkan vagina mengalami gata-gatal dan berbau (Fitriyah, 2014). Penggunaan celana dalam yang ketat juga tidak disarankan agar terhindar dari rasa gatalgatal pada alat kelamin (Manan, 2011). Beberapa responden penelitian lebih memilih menggunakan celana dalam yang ketat dibanding celana dalam yang longgar saat menstruasi. Hal ini juga dialami oleh responden penelitian Fitriyah (2014) dan Yuliarti (2014) bahwa saat menstruasi responden lebih suka menggunakan celana dalam yang ketat. Mereka kurang mengetahui bahwa celana dalam yang ketat akan menyebabkan daerah kewanitaan lembab karena kulit susah bernapas, memudahkan jamur berkembang biak dan menimbulkan iritasi pada organ kewanitaan.

Penggunaan pembalut yang bersih sudah menjadi hal yang harusnya dilakukan saat menstruasi, tapi tidak dengan siswi SDN Kamoning yang masih beberapa siswi menggunakan kain sebagai pembalut saat menstruasi. Penggunaan kain sat menstruasi dan dipakai ulang setelah di cuci lalu dikeringkan sangatlah tidak disarankan. Tindakan ini berisiko terhadap tumbuhnya mikroba dan larva serangga sehingga menggunakan pembalut yang siap pakai, bukan pembalut kain, karena dikhawatirkan pembalut kain kurang bersih akibat perawatannya yang kurang baik (Ali and Mohammad, 2007). Persepsi siswi tentang risiko tidak melakukan higiene menstruasi menunjukkan bahwa perepsi mereka banyak yang keliru/tidak benar. Hal ini karena pemahaman tentang higiene menstruasi yang kurang (Fitriyah, 2014).

\section{Keinginan Siswi SDN Kamoning Dalam Menjaga Higiene Menstruasi}

\begin{abstract}
Keterpaparan dengan informasi mempengaruhi pengetahuan sehingga individu yang berperilaku buruk disebabkan karena memiliki pengetahuan yang kurang dan kepercayaan yang dianutnya. Pengetahuan adalah hasil penginderaan manusia terhadap objek melalui indera yang dimilikinya baik penglihatan, pendengaran, penciuman. Pengetahuan merupakan konstruksi kognitif seseorang terhadap objek, pengalaman dan lingkungan yang telah diketahui, dipersepsikan, diyakini, sehingga menimbulkan motivasi keinginan untuk bertindak, pada akhirnya perwujudan keinginan tersebut menghasilkan sebuah perilaku. Perilaku yang didasari oleh pengetahuan akan lebih langgeng daripada perilaku yang tidak didasari pengetahuan (Notoadmodjo, 2007).

Teori HAPA menjelaskan bahwa seseorang akan memiliki keinginan dalam bertindak salah satunya jika ia memiliki persepsi risiko yang benar sehingga terdapat hubungan antara persepsi risiko dengan keinginan seseorang untuk melakukan suatu tindakan. Siswi SDN Kamoning yang tidak memiliki keinginan melakukan higiene menstruasi.
\end{abstract}

\section{SIMPULAN}

Ada hubungan antara persepsi risiko dengan keinginan dalam menjaga higiene menstruasi, sehinngga orang yang memiliki persepsi risiko keliru cenderung tidak melakukan higiene menstruasi. karena sebagian besar masih memiliki persepsi risiko yang masih keliru, sedangkan siswi yang memiliki keinginan kemungkinan besar memiliki persepsi risiko yang benar tentang dampak tidak menjaga higiene menstruasi (keputihan). Diharapkan Puskesmas bisa memberikan sosialisasi kepada siswi SDN Kamoning tentang cara 
menjaga higiene menstruasi dan dampak jika tidak menjaga higiene menstruasi.

Diharapkan Sekolah mengaktifkan kembali UKS yang ada, guna diadakannya konseling tentang kesehatan reproduksi remaja khususnya cara menjaga higiene menstruasi. Diharapkan siswi yang sudah menstruasi setelah diberi leaflet tentang cara menjaga higiene menstruasi, pengetahuan siswi tentang higiene menstruasi bertambah sehingga tidak mempunyai persepsi keliru lagi.

\section{DAFTAR PUSTAKA}

Ali,M., and Mohammad, A., 2007. Psikologi remaja perkembangan peserta didik. Jakarta : PT Bumi aksara.

Anurogo, D., and Wulandari, A., 2011. Cara jitu mengatasi nyeri haid. Yogyakarta : ANDI

Bandura, A., 1997. Social foundation of thought and action. Englewood cliffs, NJ : Prentice Hall.

Bobak., and jensen, L., 2005. Buku ajar keperawatan maternitas. Jakarta : EGC

Davey, P. 2005. At a Glance Medicine. Jakarta : Erlangga.

Fitriyah, I., 2014. Gambaran Perilaku Higiene Menstruasi Pada Remaja Putri Di Sekolah Dasar Negeri Di Wilayah Kerja Puskesmas Pisangan. Skripsi. Universitas Islam Negeri Hidayatullah.

Ginarhayu. 2013. Analisis faktor-faktor yang berhubungan dengan usia menarche remaja putri (9-15 tahun) pada siswi sekolah dasar dan sekolah lanjutan tingkat pertama di jakarta pada tahun 2013. Tesis. Universitas indonesia.

Indah, F.T.N., 2013. Kejadian Pruritus Saat Menstruasi Pada Remaja Putri (Stusi pada siswi SMAN1 Ngimbang Kabupaten Lamongan.

Iskandar, S.S., 2015. Awas keputihan bisa mengakibatkan kematian dan kemandulan.
Jones. 2009. Kebersihan organ genetalia wanita. Yogyakarta : Fitramaya.

Kurniawati, C.V., 2014. Aplikasi teori health belief model terhadap perilaku remaja putri dalam pencegahan patologis keputihan. Skripsi. Fakultas Kesehatan Masyarakat Universitas Airlangga.

Kusmiran, E.,2012. Kesehatan Reproduksi Remaja Dan Wanita. Jakarta : Salemba Medika.

Mahfiana, L., Elfi,Y.R. dan Retno,W. 2009. Remaja dan Kesehatan Reproduksi. Ponorogo : STAIN Ponorogo Press.

Manan, E., 2011. Miss V. Yogyakarta : Buku Biru.

Nasdaldy. 2012. Jenis kanker leher rahim, pencegahan, deteksi dini.

Notoadmodjo, S. 2007. Promosi kesehatan dan ilmu perilaku. Jakarta : Rineke Cipta.

Panda et al. Incidence of candidiasis and trichomoniasis in leucorrhoea patients. IJCRR Vo 05 issue 03 . 2013.

Proverawati and Misaroh. 2009. Menarche dan menstruasi pertama penuh makna. Yogyakarta : Nuha medika.

Pudiastuti, R.D. 2012. 3 Fase penting pada wanita (Menarche, Menstruasi, dan Menopause).

Pulungan, P.W. 2009. Gambaran usia menarche pada remaja putri di SMP Shafiyyatul Amaliyyah dan SMP Nurul Hasanah. Skripsi. Universitas Sumatera Utara.

Rahayu, R.T., Aminoto, C., and Madkhan, M., 2012. Efektivitas penyuluhan peer group dengan penyuluhan oleh petugas kesehatan terhadap tingkat pengetahuan tentang menarche. Jurnal ilmiah kesehatan keperawatan. Vol.8, No.2, Hal. 3136.

Rahmat, J., 2000. Psikologi komunikasi. Bandung : Remaja Karya

Rahmatika, D., 2012. Pengaruh pengetahuan dan sikap tentang personal hygiene menstruasi terhadap tindakan personal hygiene 
remaja putri pada saat menstruasi di SMK Negeri 8 Medan tahun 2010. Tesis. Universitas sumatera utara. Tersedia dia repository.usu.ac.id diakses tanggal 3 Desember 2016.

Rimawati, E., 2012. Kebersihan organ reproduksi pada perempuan pedesaan di kelurahan polaman kecamatan mijen semarang.

Riskesdas. 2013. Laporan Riset Kesehatan Dasar 2010.

Santrock, J.W. 2009 Adolescene Perkembangan Remaja. Jakarta : Erlangga

Sugiyono. 2007. Metode Penelitian Bisnis. CV Alfabeta : Bandung.
Sulaiman, A., 2017. Angka kematian ibu di Sampang menurun.

Suryati. 2012. Perilaku kebersihan remaja saat menstruasi. Jurnal Health Quality. Vol. 3, No.1.

Setiawan, A., and Saryono., 2010. Metodelogi penelitian kebidanan. Jakarta: Nuha Medika

Widyastuti, Rahmawati, and Purnamaningrum., 2009. Kesehatan reproduksi. Yogyakarta : Fitramaya

Yuliarti. 2014. Higiene menstruasi remaja awal. Jakarta : Sagung Seto. 